\title{
POST FIRE GROUND VEGETATION DEVELOPMENT OVER 25 YEARS
}

\author{
*Lāsma Freimane ${ }^{1,2}$, Linda Čakša' ${ }^{1}$, Annija Kārkliṇa ${ }^{1}$, Didzis Elferts ${ }^{1,3}$, Beāte Bērziṇa \\ ${ }^{1}$ Latvian State Forest Research Institute 'SILAVA', Latvia \\ ${ }^{2}$ Latvia University of Life Sciences and Technologies, Latvia \\ ${ }^{3}$ University of Latvia, Latvia \\ *Corresponding author's email: lasma.freimane@1lu.lv
}

\begin{abstract}
Fire has been a part of natural disturbance regime in boreal and to some extent also hemiboreal forests, affecting soil and light conditions, seedbanks, trees and ground vegetation. The most significant factors affecting occurrence, severity and size of forest fires are anthropogenic, weather and the environment, all of which are changing due to human-caused climate change. This paper discusses medium term (25 years) vegetation development in five different biotopes after fire disturbance. Sample plots were established in Slitere Reserve (now National park) in north-western Latvia on areas affected by large fire in 1992. Data were collected in 1993, 2002 and 2017. The aim of the study was to characterize the regeneration and succession of ground vegetation after the fire.

In 1993, species such as bog-rosemary (Andromeda polifolia), heather (Calluna vulgaris) and cloudberry (Rubus chamaemorus) were observed in the ground vegetation a year after the fire. In 2002 liverworts appeared, indicating that the bog has acquired more stable and wetter conditions, but in 2017, liverwort mosses were no longer present and the percentage cover of Rubus chamaemorus decreased significantly and Calluna vulgaris, sphagnum sp., and Betula pendula were present in large quantities in the bog. Comparing these studied years, it can be concluded that all these years the biotopes and species have continuously developed and are regenerating.
\end{abstract}

Key words: fire disturbance, long-term recovery, vegetation regeneration, hemiboreal forests.

\section{Introduction}

Fires is a part of natural disturbances in hemiboreal forests and has profound influence on vegetation succession and biodiversity (Granström, 2001; Jõgiste et al., 2017). Most of the fires had been human-induced; however, meteorological conditions play an important role both in initial stages of forest fire occurrence as well as potential of its spread and severity (Donis et al., 2017; Kitenberga et al., 2018). Bogs are an important part of the forest ecosystem, as moist wetland habitats, bog burns less often than forests, and the few fires that do occur are usually limited to the margins (Sillasoo et al., 2011). The development of vegetation after a fire mainly depends on two factors: fire severity, and the structure of vegetation before the fire (Sillasoo et al., 2011). Frequency of fires has increased as a result of global warming (Flannigan et al., 2006). Habitat recover after fire disturbance differs from that of any other severe disturbance (Wang \& Kemball, 2005) due to influence to recovery of trees as defining element of forest ecosystem (Mara Kitenberga et al., 2020), as well as effect on organic matter and thus disruption of nutrient supply differing from any other severe humaninduced or natural disturbance (Čakšs et al., 2018; Jansons et al., 2016; Samariks et al., 2020, 2021). The development of burned biotope depends on how quickly the fire is extinguished and what is done with the stand after the fire, for example, whether salvage logging is carried out or left for natural regeneration (Kārkliņa et al., 2020).

Climate changes significantly affect not only the increment of trees (Augustaitis et al., 2015; Jansons et al., 2015) or damages directly (Zeltińš et al., 2018;
Zeltiňš et al., 2016) or indirectly (Arhipova et al., 2015; Burneviča et al., 2016), but also abiotic damages, like occurrence of forest fires (Drobyshev et al., 2021). The fire significantly affects the dynamics of forest development by changing soil properties, limiting fire-sensitive species and promoting the spread of pyrophilic species (Bond et al., 2005; Certini, 2005). An intensive fire could impact the future regeneration of the understory structure. However, contrary to other disturbances, fire is a disturbance whose strength and nature can influence the composition of the concrete forest stand, such as the composition of vegetation and the density of undergrowth trees (Bond et al., 2005). For example, in a habitat where dominant species are heather and juniper, the fire will spread much faster and more widely throughout the area (Mallik \& Gimingham, 1984). Forest fires typically divide into three groups based on their intensity and severity: 1. Ground fire - fire spreads in peat or humus layer, often without visible flames above ground level; 2. Surface fire - fire spreads in litter and undergrowth vegetation; 3 . Crown fire - fire spreads from tree crown to crown, which is high-intensity stand-replacing fires (Roga, 1979).

Also, the speed and direction of vegetation succession are determined by soil factors and tree crown openness after fire and management (salvage logging) (Nilsson \& Wardle, 2005), and are linked to post -disturbance stand characteristics (Bāders et al., 2021). Light conditions are changing during the forest succession; more diverse vegetation may develop in the burned area, and more shade-intolerant tree species may also enter (Hart \& Chen, 2017). Also, fire 
disturbances can change the pattern of competition between stand and ground vegetation, resulting in changes in vegetation structure (Angelstam \& Kuuluvainen, 2004). Most of post-fire studies have focused on tree recovery (Angelstam \& Kuuluvainen, 2004), but studies about vegetation development after fire data were collected shortly after a fire (Marozas et al., 2007; Schimmel \& Granstrom, 1996), especially researches about different biotopes like bogs are lacking. Several studies indicate that after fire at the beginning of the stand succession when topsoil is revealed, rapidly developing heather, which is a well-adapted specie in such condition and can form a monodominant cover in a stand (M.-C. Nilsson et al., 1996; Parro et al., 2009; Reich et al., 2001). Shrub layer starts to recover and stabilize within 5-15 years after burning, but the complete structure of the forest stand re-establishes 120-140 years after the fire (Gorshkov \& Bakkal, 1996), even so much more rapid recovery can be expected and is observed after natural disturbances (Baders et al., 2017). It is crucial to understand the development of understorey vegetation growth after the fire. The bog has reached the recovery level of the ecosystem, ruderal and pioneer species have disappeared (Pakalne, 1998). Furthermore, any information that provides an accurate insight into this recovery is relevant. Therefore, any information about the forest stand development after the fire disturbance in a long-term period is essential (Kitenberga, 2019), where in our case, there are different bog habitats where forest areas are also included.

The aim of the study was to characterize the regeneration and succession of ground vegetation after the fire, based on the species composition of the ground vegetation. We hypothesized that: 1) 25 years after the fire, the vegetation has changed compared to the vegetation data in previous years 2) over time, pioneer species have disappeared, and the characteristic species are dominating, indicating a complete recovery of the studied site.

\section{Materials and Methods}

In the summer of 1992, a forest fire broke out in Slitere Reserve's territory, where 3200 ha of forests and bog were burned. To find out the condition of plant communities and the course of regeneration, the study already started one month after the fire and continued until 2002 (I. Rēriha). According to Latvian State Forest data, vegetation data were collected in five forest quarters $(70 ; 85 ; 91 ; 110 ; 127)$ which best describe the whole bog area and include the most characteristic biotopes. In 1992, permanent plots were created to return every year and find each sample plot and count the vegetation.

The placement points of the permanent sampling plots were selected at random principle, where
40 points selected and marked in the three forest quarters, 60 points in the quarter of 70 , and 20 points in 91 quarter. At each selected point, 50 x $50 \mathrm{~cm}$ sample plots which were oriented diagonally (each plot corner oriented to the north, south, east and west) were created. Sampling plots were located in the following habitats: 1) high bog (PU) - bog with mosses and few pines up to $1.5 \mathrm{~m}$ high; 2 ) old dunes kangars (K), - a dry habitat which is similar to dry pine forests; 3 ) old flat dunes lēzens kangars (LK) - where the absolute height does not exceed $0.5 \mathrm{~m}$; 4) marsh (ZP); 5) bog (PA) - high bog with pines up to $2 \mathrm{~m}$ high; niedrājs (N) - wet peat biotope.

According to the same method as in previous years, the latest vegetation data was collected in 2017 (Latvian State Forest Research Institute "Silava"). As it was not possible to identify all the plots from previous years, the statistical analyses included only data from those identified plots (in total 640 plots were identified). To see the differences and tendencies of vegetation development, the data of 1993, 2002 and 2017 were used in the analyses (in total 372 sampling plots). All analyses performed in the statistical program R 4.1.0 (R Core Team, 2020), using packages "vegan", "readxl", “tidyverse", "ggrepel". The ground cover vegetation communities were assessed by the Detrended Correspondence Analysis (DCA), a multivariate orthogonal ordination method. The analysis of similarities (ANOSIM), a non-parametric ANOVA-like test based on the ranked dissimilarity matrix (Clarke 1993), was used to compare species composition between the years.

\section{Results and Discussion}

The statistical comparison of the ground cover vegetation between the selected years (1993, 2002 and 2017) showed significant ( $p$-value $<0.001$ ) differences amongst all years. This shows that the vegetation has changed over the last 25 years and the current vegetation in the last year of the survey is different. But in Figure 1 of the ordination, it can be seen that the growing conditions in biotopes in 2002 and 2017 were different compared with 1993, where the grouping of species is more pronounced. The first two DCA ordination axis were significant ( $p$-values $<0.01$ and showed that the vegetation and growth conditions of the analysed biotopes have changed over the years (Figure 1). These results indicate a continuous change in the composition of the plant species, where new species have been introduced in each period. First axis of the DCA analysis clearly presents light conditions, where it can be seen that the amount of light decreases due to the regeneration of trees such as silver birch Betula pendula and more mosses that can grow in shady conditions: Plagiomnium affine, Climacium dendroides, etc. The gradient captured by the second 


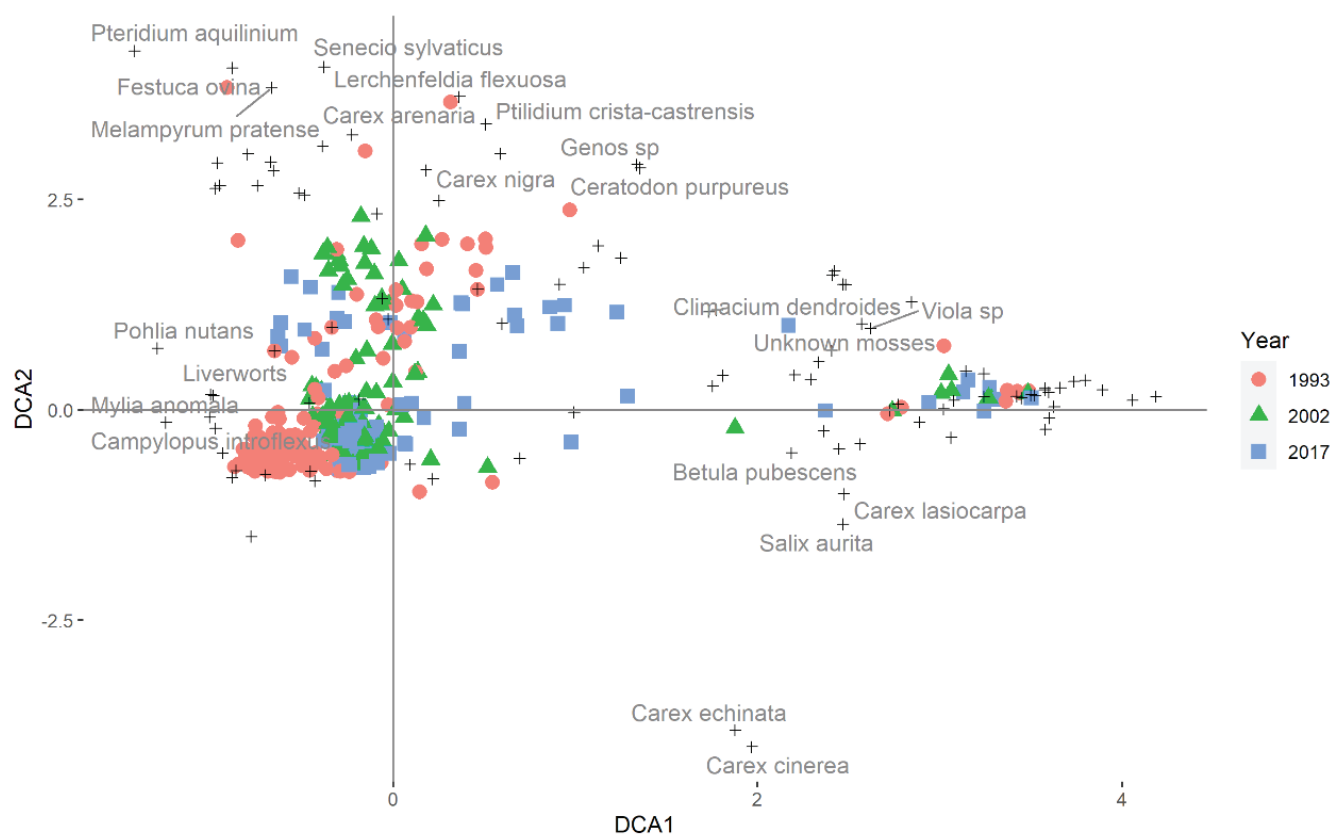

Figure 1. The detrended correspondence analysis ordination of the ground cover vegetation in all studied biotopes by years.

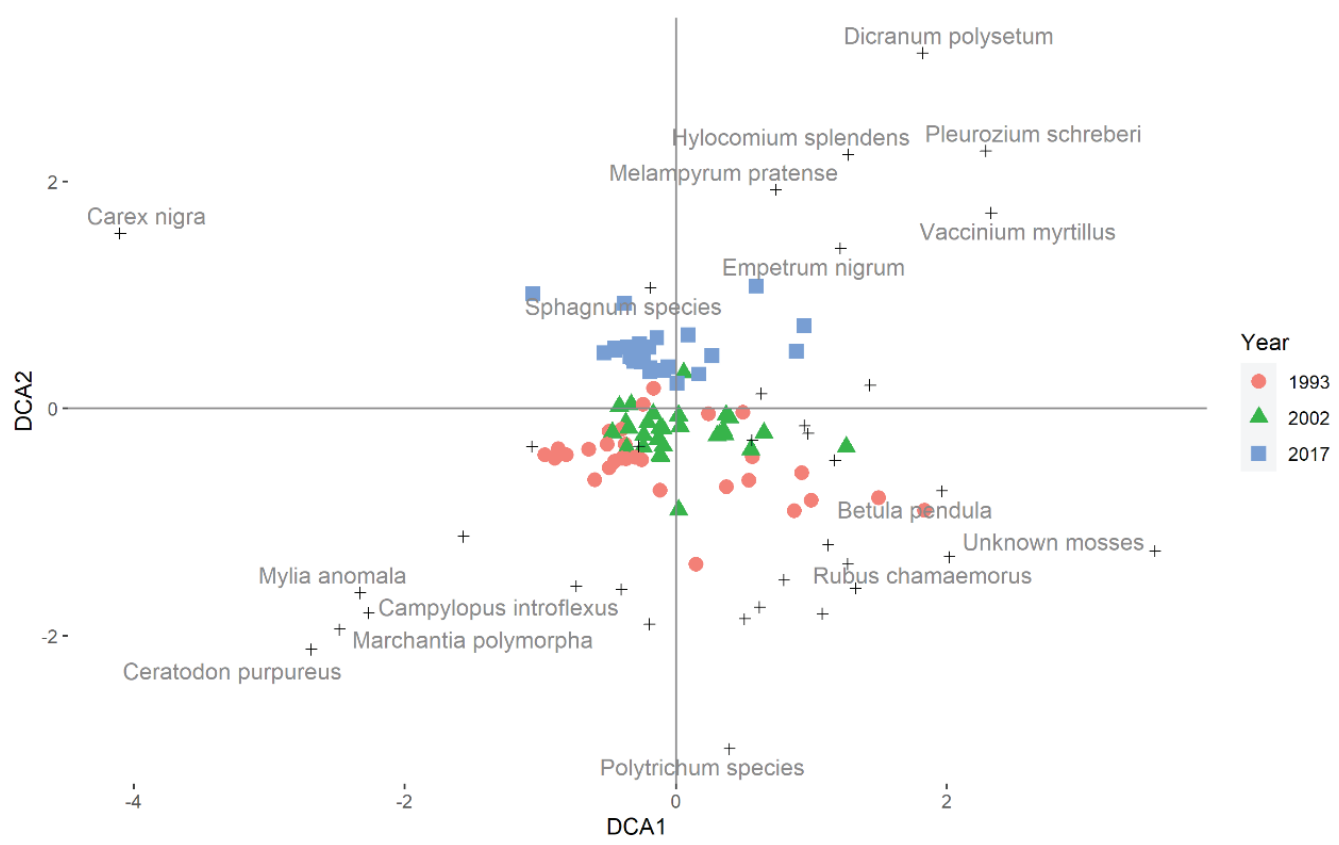

Figure 2. The detrended correspondence analysis ordination of the ground cover vegetation in the high bog biotope by years.

axis (DCA2) might be related to the moisture regime of the biotopes, as in the upper part of the axis are species which are growing in dry areas (Cladonia species, Festuca ovina, Deschampsia flexuosa) which indicates that by 2002 the moisture regime had increased and dry habitat species had disappeared, because, as we can see in Figure 1, these species only occured in 1993 (Figure 1) (Frego, 1996).
Sphagnum species also showed a continuous regeneration ten years after the fire disturbance. The percentage cover of sphagnum moss species in the year 1993 was $4.6 \%$, but between the year 2002 and the year 2017, sphagnum mosses have a stable percentage cover: $52 \%$ and $58 \%$, respectively. As well as in the biotopes, where in 1993-year heather was a minimal percentage cover $(\sim 2 \%)$ (except for 
ZP) showed high cover in $2002(\sim 40 \%)$ maintaining similar cover in 2017 as well. These results showed the contradictory result with other research about the fire disturbance, which says that five years after the fire, the biotopes, where are dry growth conditions, must change from the dominance of the heather to the dominance of cowberries (Vaccinium vitis-idaea) and bilberries (Vaccinium myrtillus) (Parro et al., 2015), which did not happen in our study, where in our dry biotopes (kangars and lēzens kangars), cowberries and bilberries almost disappeared, which is in line with the fact that the limiting factor for these shrubs is fire (Niklasson \& Granström, 2000; Schimmel \& Granstrom, 1996). Looking at each habitat separately

Table 1

Percentage cover of ground vegetation in the studied biotopes ( $\mathrm{K}$ - kangars; LK - lēzens kangars; $\mathrm{N}$ - niedräjs; PA - bog; PU - high bog; ZP - marsh)

(Liverwort mosses were not identified by species; hence all are defined as: liverworts)

\begin{tabular}{|c|c|c|c|c|c|c|c|c|c|c|c|c|c|c|c|c|c|c|}
\hline Biotope & $\mathbf{K}$ & $\mathbf{K}$ & $\mathbf{K}$ & LK & LK & LK & $\mathbf{N}$ & $\mathbf{N}$ & $\mathbf{N}$ & PA & PA & PA & PU & PU & PU & $\mathbf{Z P}$ & $\mathbf{Z P}$ & $\mathbf{Z P}$ \\
\hline Year & $\tilde{\sigma}$ & ฮิ & 공 & ڤ̊ & 气ิ & 록 & 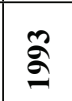 & ฮิ & 록 & ڤ̆ & 气ิ & 촉 & ڤ̆ & ฮิ & 굴 & ڤ̆ & 气ิ & 롱 \\
\hline Liverworts & & 3.7 & & & 3.7 & & & & & & 7.4 & & & 9.8 & & & & \\
\hline $\begin{array}{l}\text { Andromeda } \\
\text { polifolia }\end{array}$ & & & 0.1 & 2.2 & 8 & 1.1 & & & & 2.1 & 10.9 & 0.3 & 5.1 & 12.3 & 0.3 & & & \\
\hline $\begin{array}{l}\text { Aulocomnium } \\
\text { palustre }\end{array}$ & & 4.3 & 2.2 & & 9.9 & 1.5 & & 15 & & 0.2 & 12.4 & 1.5 & 1 & 12.1 & 1.3 & 0.25 & 6 & \\
\hline Betula pendula & & 3.7 & & & 3.7 & 0.25 & & & & & 3.75 & 1.6 & & 3.8 & 0.8 & & & 2.4 \\
\hline Betula pubescens & & 1.4 & & 1.2 & 4.3 & & 1 & 11.2 & & 1.5 & 10 & & 0.3 & 5.6 & & 3.8 & 7.9 & \\
\hline Calluna vulgaris & 2 & 30.3 & 31.7 & 3.6 & 26 & 34. & & & & 3 & 28.5 & 36.4 & 6.3 & 22.1 & 33.3 & & & \\
\hline Cladonia species & & 22.4 & 10.6 & & 13.3 & 3.6 & & 3.7 & & & 5.3 & 2.5 & & 5 & 0.1 & & & \\
\hline $\begin{array}{l}\text { Eriophorum } \\
\text { vaginatum }\end{array}$ & & 3.7 & 0.2 & 4.5 & 14.03 & 15.7 & 4 & 11.2 & & 15.7 & 22.0 & 8.5 & 14.2 & 22.7 & 17 & & & 0.1 \\
\hline Ledum palustre & 0.2 & 9.3 & 0.2 & 3.0 & 18.2 & 7.7 & 4. & 27.5 & & 9.4 & 28.7 & 14 & 6.9 & 18.8 & 7.3 & & 3.8 & \\
\hline $\begin{array}{l}\text { Oxycoccus } \\
\text { palustris }\end{array}$ & & & 0.1 & 1.3 & 13.7 & 3.4 & 0.5 & 21.2 & 1.5 & 4.4 & 18.6 & 4.2 & 5.3 & 20.9 & 4.4 & 0.2 & 6.3 & 1.8 \\
\hline $\begin{array}{l}\text { Peucedanum } \\
\text { palustre }\end{array}$ & & & & & & 0.75 & & & & & & & & & & & 7.5 & 0.4 \\
\hline Pinus sylvestris & 0.5 & 6.2 & 1 & 0.4 & 6.3 & 3.71 & 0.25 & & & 0.4 & 5.6 & 1.5 & 0.3 & 3 & 0.6 & 0.2 & & 0.2 \\
\hline $\begin{array}{l}\text { Pleurozium } \\
\text { schreberi }\end{array}$ & & 6 & 19.5 & & 11.2 & 32.7 & & & & & 2 & 2 & & 3.7 & 16.4 & & 1 & 2.3 \\
\hline $\begin{array}{l}\text { Polytrichum } \\
\text { juniperinum }\end{array}$ & 0.2 & 36.2 & 1.4 & 2.9 & 15.2 & 10.3 & 7.5 & 7.5 & 6.5 & 3.1 & 22.7 & 2.3 & 2.6 & 17.3 & 2 & 3.75 & 7.5 & 0.5 \\
\hline $\begin{array}{l}\text { Rubus } \\
\text { chamaemorus }\end{array}$ & & 0.2 & & 13 & 23.3 & 0.62 & & & & 15.3 & 21.5 & 5.6 & 14.0 & 21.7 & 5.1 & & & \\
\hline $\begin{array}{l}\text { Sphagnum } \\
\text { species }\end{array}$ & & 3.7 & & 0.2 & 19.2 & 54.8 & 27.5 & 83.7 & 89 & 6.2 & 53.7 & 64.9 & 10.1 & 55.13 & 69.3 & 11.3 & 16.2 & 2.3 \\
\hline $\begin{array}{l}\text { Vaccinium } \\
\text { myrtillus }\end{array}$ & 1 & 11.7 & 0.6 & 6.9 & 19.6 & 15.2 & & & & 12.8 & 12.1 & 0.9 & & & 2.7 & & & \\
\hline $\begin{array}{l}\text { Vaccinium } \\
\text { uliginosum }\end{array}$ & 0.2 & 3.7 & 1.2 & 10.8 & 23.0 & & & & & 5.2 & 23.3 & 11.2 & & & & & & \\
\hline $\begin{array}{l}\text { Vaccinium vitis- } \\
\text { idaea }\end{array}$ & 1.8 & 12 & 3.9 & 5.9 & 22.1 & 7.2 & & & & 4.8 & 10.5 & 2.4 & 6.7 & 12 & 5.9 & & 7.5 & 0.12 \\
\hline
\end{tabular}


in the DCA analysis, it can also be seen that the composition of the species is variable, but 10 years after the fire the biotope growth conditions are more stable and are characterized by more typical species (Figure 2; as an example, a high bog is inserted), also statistical analysis showed the difference between the species in the studied years. Variability in species cover over the studied years can also be seen by visually looking at the table with biotopes and the percentage cover of the most common species (Table 1).

\section{Conclusions}

1. 25 years after the forest fire, biotopes showed continuous vegetation development throughout the research period.
2. The vegetation percentage cover of certain species indicates that first signs of stability of ground cover is observed 10 years after the fire, which indicate the recovery after fire.

3. Fire is a significant disturbance that has a longterm effect on biotope.

\section{Acknowledgements}

We acknowledge the work of Ilze Rēriha in establishment and maintenance of the transects. The study was carried out in LVM project "Impact of forest management on forest and related ecosystem services". We acknowledge the permission of Nature Conservation Agency to collect the data for this study.

\section{References}

Angelstam, P., \& Kuuluvainen, T. (2004). Boreal forest disturbance regimes, successional dynamics and landscape structures: a European perspective. Ecological Bulletins, 51, 117-136. DOI: 10.2307/20113303.

Arhipova, N., Jansons, A., Zaluma, A., Gaitnieks, T., \& Vasaitis, R. (2015). Bark stripping of Pinus contorta caused by moose and deer: Wounding patterns, discoloration of wood, and associated fungi. Canadian Journal of Forest Research, 45(10), 1434-1438. DOI: 10.1139/cjfr-2015-0119.

Augustaitis, A., Kliučius, A., Marozas, V., Pilkauskas, M., Augustaitiene, I., Vitas, A., Staszewski, T., Jansons, A., \& Dreimanis, A. (2015). Sensitivity of European beech trees to unfavorable environmental factors on the edge and outside of their distribution range in northeastern Europe. IForest-Biogeosciences and Forestry, 9(2), 259-269.

Bāders, E., Jõgiste, K., Elferts, D., Vodde, F., Kiviste, A., Luguza, S., \& Jansons, Ā. (2021). Storm legacies shaping post-windthrow forest regeneration: learnings from spatial indices in unmanaged Norway spruce stands. European Journal of Forest Research, 0123456789. DOI: 10.1007/s10342-021-01368-x.

Baders, E., Senhofa, S., Purina, L., \& Jansons, A. (2017). Natural succession of Norway spruce stands in Hemiboreal forests: Case study in Slitere national park, Latvia. Baltic Forestry, 23(2), 522-528.

Bond, W.J., Woodward, F.I., \& Midgley, G.F. (2005). The global distribution of ecosystems in a world without fire. New Phytologist, 165(2), 525-538. DOI: 10.1111/j.1469-8137.2004.01252.x.

Burneviča, N., Jansons, Ā., Zal̦uma, A., Kḷavin̦a, D., Jansons, J., \& Gaitnieks, T. (2016). Fungi inhabiting bark stripping wounds made by large game on stems of picea abies (L.) Karst. in Latvia. Baltic Forestry, 22(1), $2-7$.

Čakšs, R., Robalte, L., Desaine, I., Džeriņa, B., \& Jansons, A. (2018). Ground vegetation composition and diversity in drained Norway spruce (Picea abies (L.) Karst.) stands 50 years after whole-tree harvesting management: Case study in Latvia. Forestry Studies, 69(1). DOI: 10.2478/fsmu-2018-0010.

Certini, G. (2005). Effects of fire on properties of forest soils: A review. Oecologia, 143(1), 1-10. DOI: 10.1007/ s00442-004-1788-8.

Donis, J., Kitenberga, M., Snepsts, G., Matisons, R., Zarins, J., \& Jansons, A. (2017). The forest fire regime in Latvia during 1922-2014. Silva Fennica, 51(5), 1-15. DOI: 10.14214/sf.7746.

Drobyshev, I., Ryzhkova, N., Eden, J., Kitenberga, M., Pinto, G., Lindberg, H., Krikken, F., Yermokhin, M., Bergeron, Y., \& Kryshen, A. (2021). Trends and patterns in annually burned forest areas and fire weather across the European boreal zone in the $20^{\text {th }}$ and early $21^{\text {st }}$ centuries. Agricultural and Forest Meteorology, 306(May), 108467. DOI: 10.1016/j.agrformet.2021.108467.

Flannigan, M.D., Amiro, B.D., Logan, K.A., Stocks, B.J., \& Wotton, B.M. (2006). Forest fires and climate change in the $21^{\mathrm{ST}}$ century. Mitigation and Adaptation Strategies for Global Change, 11(4), 847-859. DOI: 10.1007/s11027-005-9020-7.

Frego, K.A. (1996). Regeneration of four boreal bryophytes: Colonization of experimental gaps by naturally occurring propagules. Canadian Journal of Botany, 74(12), 1937-1942. DOI: 10.1139/b96-231.

Gorshkov, V.V., \& Bakkal, I.J. (1996). Species Richness and Structure Variations of Scots Pine Forest Communities during the Period from 5 to 210 Years after Fire. Silva Fennica, 30(2-3), 329-340.

Granström, A. (2001). Fire management for biodiversity in the European boreal forest. Scandinavian Journal of Forest Research, 16(1), 62-69. DOI: 10.1080/028275801300090627. 
Hart, S.A., \& Chen, H.Y.H. (2017). Fire, Logging, and Overstory Affect Understory Abundance, Diversity, and Composition in Boreal Forest Author (s): Stephen A. Hart and Han Y. H. Chen Published by: Wiley on behalf of the Ecological Society of America Stable URL: http://www.jstor. 78(1), 123-140.

Jansons, Ā., Robalte, L., Čakšs, R., \& Matisons, R. (2016). Long-term effect of whole tree biomass harvesting on ground cover vegetation in a dry Scots pine stand. Silva Fennica, 50(5). DOI: 10.14214/sf.1661.

Jansons, Ā., Matisons, R., Zadinaa, M., Sisenis, L., \& Jansons, J. (2015). The effect of climatic factors on height increment of scots pine in sites differing by continentality in Latvia. Silva Fennica, 49(3), 1-14. DOI: $10.14214 /$ sf. 1262 .

Jõgiste, K., Korjus, H., Stanturf, J.A., Frelich, L. E., Baders, E., Donis, J., Jansons, A., Kangur, A., Köster, K., Laarmann, D., Maaten, T., Marozas, V., Metslaid, M., Nigul, K., Polyachenko, O., Randveer, T., \& Vodde, F. (2017). Hemiboreal forest: Natural disturbances and the importance of ecosystem legacies to management. Ecosphere, 8(2). DOI: 10.1002/ecs2.1706.

Kārkliņa, A., Brūmelis, G., Dauškane, I., Elferts, D., Freimane, L., Kitenberga, M., Lībiete, Z., Matisons, R., \& Jansons, A A. (2020). Effect of salvage-logging on post-fire tree establishment and ground cover vegetation in semi-natural hemiboreal forests. Silva Fennica, 54(5), 1-16. DOI: 10.14214/sf.10334.

Kitenberga, M. (2019). Forest fire history and post-fire regeneration patterns in hemiboreal forests. Latvia University of Life Sciences and Technologies.

Kitenberga, M., Elferts, D., Adamovics, A., Katrevics, J., Donis, J., Baders, E., \& Jansons, A. (2020). Effect of salvage logging and forest type on the post-fire regeneration of Scots pine in hemiboreal forests. New Forests, 51(6), 1069-1085. DOI: 10.1007/s11056-020-09775-5.

Kitenberga, M., Matisons, R., Jansons, A., \& Donis, J. (2018). temperature and forest fires in Latvia and Estonia. 52(1).

Mallik, A.U., \& Gimingham, C.H. (1984). Ecological effects of heather burning. Journal of Ecology, 72(2), 767-776.

Marozas, V., Racinskas, J., \& Bartkevicius, E. (2007). Dynamics of ground vegetation after surface fires in hemiboreal Pinus sylvestris forests. 250, 47-55. DOI: 10.1016/j.foreco.2007.03.008.

Nesterovs, V. (1954). General forestry. Latvian State Publishing House.

Niklasson, M., \& Granström, A. (2000). Numbers and sizes of fires: long-term spatially explicit fire history in a swedish boreal landscape. Ecology, 81(6), 1484-1499.

Nilsson, M.-C., Steijlen, I., \& Zackrisson, O. (1996). No Title. Canadian Journal of Forest Research, 26, 945-953.

Nilsson, M., \& Wardle, D.A. (2005). Understory vegetation as a forest ecosystem driver: evidence from the northern Swedish boreal forest.

Pakalne, M. (1998). Characteristics of bog vegetation. In V. Kreile, M. Laivin̄š, \& A. Namatēva (Eds.), Latvian bog vegetation classification and dynamics. (p. 92).

Parro, K., Köster, K., Jõgiste, K., \& Vodde, F. (2009). Vegetation Dynamics in a Fire Damaged Forest Area: the Response of Major Ground Vegetation Species. Baltic Forestry, 15(2), 206-215.

Parro, K., Metslaid, M., Renel, G., Sims, A., Stanturf, J. A., Jõgiste, K., \& Köster, K. (2015). Impact of postfire management on forest regeneration in a. 1197(June), 1192-1197.

R Core Team. (2020). R: A language and environment for statistical computing. R Foundation for Statistical Computing. Retrieved February 13, 2021, from https://www.r-project.org/.

Reich, P.B., Bakken, P., Carlson, D., Frelich, L.E., Friedman, S.K., \& Grigal, D.F. (2001). Influence of logging, fire, and forest type on biodiversity and producticity in southern boreal forests. Ecology, 82(10), 27312748.

Roga, A. (1979). Types of forest fires, their extinguishing methods and tactics. LZTIZPI.

Samariks, V., İstenais, N., Seipulis, A., Miezīte, O., Krišāns, O., \& Jansons, Ā. (2021). Root-soil plate characteristics of silver birch on wet and dry mineral soils in Latvia. Forests, 12(1), 1-9. DOI: 10.3390/ f12010020.

Samariks, V., Krisans, O., Donis, J., Silamikele, I., Katrevics, J., \& Jansons, A. (2020). Cost-benefit analysis of measures to reduce windstorm impact in pure Norway Spruce (Picea abies L. Karst.) stands in Latvia. Forests, 11(5). DOI: 10.3390/F11050576.

Schimmel, J., \& Granstrom, A. (1996). Fire severity and vegetation response in the boral swedish forest. Ecology, 77(5), 1436-1450.

Sillasoo, Ü., Väliranta, M., \& Tuittila, E.S. (2011). Fire history and vegetation recovery in two raised bogs at the Baltic Sea. Journal of Vegetation Science, 22(6), 1084-1093. DOI: 10.1111/j.1654-1103.2011.01307.x. 
Wang, G.G., \& Kemball, K.J. (2005). Effects of fire severity on early development of understory vegetation. 262, 254-262. DOI: 10.1139/X04-177.

Zeltińš, P., Katrevičs, J., Gailis, A., Maaten, T., Baders, E., \& Jansons, A. (2018). Effect of stem diameter, genetics, and wood properties on stem cracking in Norway spruce. Forests, 9(9), 1-10. DOI: 10.3390/ f9090546.

Zeltiňš, P., Katrevičs, J., Gailis, A., Maaten, T., Jansons, J., \& Jansons, Ā. (2016). Stem cracks of Norway spruce (Picea abies (L.) Karst.) provenances in Western Latvia. Forestry Studies, 65, 57-63. DOI: 10.1515/fsmu2016-0012. 